S. M. Kovalenko ${ }^{1}$, O. S. Romelashvili ${ }^{1}$, T. V. Zborovska ${ }^{1}$, O. D. Blagun ${ }^{2}$

${ }^{1}$ National University of Pharmacy of the Ministry of Health of Ukraine

${ }^{2}$ National Pirogov Memorial Medical University, Vinnytsya, Ukraine

\title{
General Aspects of Introduction of Management Systems in Educational Organizations in Pursuance OF ISO 21001:2018
}

Aim. Analyze the requirements to and specific features of introduction of ISO 21001:2018 "Educational Organizations. Management Systems for Educational Organizations. Requirements with Guidance for Use".

Results. On the whole, the international standard ISO 21001:2018 represents a management tool for organizations providing the educational products and services that are willing and capable of satisfying the expected needs of the learners. The educational organizations promoting the compliance with ISO 21001:2018 benefit from the enhancing efficiency of educational organization management systems, continuous monitoring of the establishment and the management processes for compliance with the mission, satisfaction of the needs and expectations of consumers of the services, individual approach toward training, expanding the involvement of the interested parties and facilitating the investments.

Conclusions. This paper proves that ISO 21001:2018 is based on process approach, risk-based thinking and performance that is based on task completion in the Plan-Do-Check-Act (or PDCA) sequence. It has been established that all requirements set forth in ISO 21001:2018 are generic and intended to be applicable to any educational institution regardless of the form, terms and methods of training. By introducing the management system, the educational organizations will demonstrate their ability to maintain competencies through teaching, learning or research, and will further enhance the satisfaction of the learners, personnel and other interested parties by way of efficient application of the management system while steadily improving their own performance.

Key words: management system; education; educational services; international standard; process approach; risk-based thinking

С. М. Коваленко ${ }^{1}$, О. С. РомелАшвілі ${ }^{1}$, Т. В. ЗБоровсьКА ${ }^{1}$, О. Д. БлАГУН ${ }^{2}$

${ }^{1}$ Національний фбарлацевтичний університет

Міністерства охорони здоров'я України

${ }^{2}$ Вінницький національний медичний університет іл. М. І. Пирогова, Украӥна

ЗАГАЛЬНІ АСПЕКТИ ВПРОВАДЖЕННЯ СИСТЕМ УПРАВЛІННЯ В ОСВІТНІХ ОРГАНІЗАЦІЯХ ВІДПОВІДНО ДО ISO 21001:2018

Метою роботи $€$ аналіз вимог та особливостей впровадження ISO 21001:2018 «Освітні організації. Системи управління в освітніх організаціях. Вимоги та настанови щодо застосовування».

Результати. У цілому міжнародний стандарт ISO 21001:2018 становить собою інструмент управління для організацій, що надають освітні продукти і послуги, які хочуть і можуть задовольнити очікувані потреби учнів. У разі впровадження вимог міжнародного стандарту ISO 21001:2018 освітні організації отримують такі переваги: підвищення ефективності систем управління освітніх закладів, постійний контроль щодо відповідності місії закладу та управлінських процесів, задоволення потреб та очікувань споживачів послуг, застосування індивідуального підходу в навчанні, розширення можливості для участі зацікавлених сторін, стимулювання впровадження інновацій.

Висновки. Доведено, що основою стандарту ISO 21001:2018 є процесний підхід, ризикорієнтоване мислення та діяльність, що грунтується на принципі виконання завдань за схемою: планування, виконання, перевірка і поліпшення заходів (Plan-Do-Check-Act, aбо PDCA). 3’ясовано, що всі вимоги ISO 21001:2018 є загальні й призначені для застосування в будь-якому навчальному закладі незалежно від форми, строків або способів навчання. Визначено, що впровадження системи управління в освітніх організаціях надасть їм змогу продемонструвати свою здатність підтримувати компетенції викладанням, навчанням або дослідженнями, а також дозволить підвищити рівень задоволеності потреб учнів, персоналу та інших зацікавлених 
сторін за допомогою ефективного застосування відповідних механізмів управління та постійного поліпшення своєї діяльності.

Ключові слова: система управління; освіта; освітні послуги; міжнародний стандарт; процесний підхід; ризик-орієнтоване мислення

\section{С. М. КовАЛЕНКо ${ }^{1}$, О. С. РомеЛАшВИЛИ ${ }^{1}$, Т. В. ЗБОРОвСКАЯ ${ }^{1}$, О. Д. БЛАГУН ${ }^{2}$ \\ ${ }^{1}$ Национальный ббарлацевтический университет \\ Министерства здравоохранения Украиньь \\ ${ }^{2}$ Винницкий национальный ледицинский университет ил. М. И. Пирогова, Украина}

\section{ОБЩИЕ АСПЕКТЫ ВНЕДРЕНИЯ СИСТЕМЫ УПРАВЛЕНИЯ В ОБРАЗОВАТЕЛЬНЫХ ОРГАНИЗАЦИЯХ В СООТВЕТСТВИИ С ТРЕБОВАНИЯМИ ISO 21001:2018}

Целью работы является анализ требований и особенностей внедрения ISO 21001:2018 «Образовательные организации. Системы управления в образовательных организациях. Требования и руководство по применению».

Результаты. В целом международный стандарт ISO 21001:2018 представляет собой инструмент управления для организаций, предоставляющих образовательные продукты и услуги, которые хотят и могут удовлетворить ожидаемые потребности учащихся. При внедрении требований международного стандарта ISO 21001:2018 образовательные организации получают следующие преимущества: повышение эффективности систем управления образовательных учреждений, постоянный контроль на соответствие миссии учреждения и управленческих процессов, удовлетворение потребностей и ожиданий потребителей услуг, применение индивидуального подхода в обучении, расширение возможности для участия заинтересованных сторон, стимулирования по внедрению инноваций.

Выводы. Доказано, что основой стандарта ISO 21001:2018 является процессный подход, риск-ориентированное мышление и деятельность, основанная на принципе выполнения задач по схеме: планирование, выполнение, контроль и улучшение деятельности (Plan-Do-Check-Act, или PDCA). Установлено, что все требования ISO 21001:2018 являются общими и предназначены для применения в любом учебном заведении независимо от формы, сроков или способов обучения. Отмечено, что внедрение системы управления в образовательных организациях позволит им продемонстрировать свою способность поддерживать компетенции посредством преподавания, обучения или исследований, а также повысить уровень удовлетворенности потребностей учащихся, персонала и других заинтересованных сторон с помощью эффективного применения механизмов управления и постоянного улучшения своей деятельности.

Ключевые слова: система управления; образование; образовательные услуги; международный стандарт; процессный подход; риск-ориентированное мышление

\section{STATEMENT OF THE PROBLEM}

Education is the basis of a productive society. Over a long period of study, people acquire not just valuable knowledge, theoretical or practical, but also attain the ability to make decisions in an efficient manner $[1,2]$.

However, the quality of educational services may vary greatly between specific organizations. That is why one needs to proceed with care when choosing the educational institution. This choice may be simpler if there is a certificate of compliance to a certain standard, such as ISO 21001:2018 - "Educational Organizations. Management Systems for Educational Organizations. Requirements with Guidance for Use" [3].

Besides, even the properly functioning schools or other educational institutions need to run regular assessment of the extent of satisfaction of educational needs of their learners and the demands of other relevant interested parties. ISO 21001:2018 may become handy in tackling this task as it sets the standards for management systems of educational institutions and outlines all necessary recommendations [3].

Like other ISO management system standards, ISO 21001:2018 is based on the Plan-Do-Check-Act principle (otherwise known as PDCA). This principle helps the organizations to assess every aspect of the standardization with due focus on social responsibility and other such aspects [3].

Introduction of ISO 21001:2018 offers endless advantages, including better alignment of the standard objectives and activities with the internal policy of each specific organization, more personalized learning, stronger confidence in the organization and engagement of the interested parties in the operation of the educational service provider. In addition, ISO 21001:2018 helps harmonize innumerable standards worldwide and fosters the sharing of the advanced experience and innovation [3]. 


\section{ANALYSIS OF RECENT RESEARCHES AND PUBLICATIONS}

Main advantages of ISO 21001:2018 - "Educational Organizations. Management Systems for Educational Organizations. Requirements with Guidance for Use" include the enhanced efficiency of educational organization management systems, continuous monitoring of the establishment and the management processes for compliance with the mission, satisfaction of the needs and expectations of consumers of the services, more personalized learning, widened participation of the interested parties and stimulation of the investments.

This standard focuses on the management systems of educational organizations as well as the impact of these on learners and other relevant interested parties. This document conforms to ISO's requirements for management system standards.

These requirements include a high level structure, identical core text, and common terms with core definitions, designed to benefit the users implementing multiple ISO management system standards $[4,5]$.

Matters pertaining to introduction of quality management systems in educational organizations are addressed by the national scholars, such as A. P. Vorobyova, I. V. Stankevich, S. O. Savchenko, P. P. Vorobiyenko, O. I. Glukhova, N. L. Kusik, S. V. Bagdikyan, O. V. Vasylevskyy, etc. [6-9].

\section{IDENTIFICATION OF ASPECTS OF THE PROBLEM UNSOLVED PREVIOUSLY}

The problem of quality personnel training is becoming particularly pressing in the economies in transition, Ukraine being one of such economies. One may single out several factors for the emerging economies which have had considerable negative impact on provision of educational services, including:

- canceled state program of job allocation for the graduates;

- shortage of professionals capable of working in market economy and oversupply of traditional professionals;

- no stable demand for professionals - graduates;

- weaker interest toward attainment of technical knowledge and becoming an engineering professional;

- decreasing funding of the general education and scientific research caused by budgetary cuts.

All these and many other problems make one seriously consider fundamental revision of the approach toward quality education assurance. Development and introduction of quality assurance systems (QAS) in accordance with international standards ISO 9001:2015 and ISO 21001:2018 is one of the ways for the higher educational institutions to survive brutal competition on the market of educational services in the sphere of higher education [3-5].
OBJECTIVE STATEMENT OF THE ARTICLE

The aim is to analyze the requirements and specific features of ISO 21001:2018 - "Educational Organizations. Management Systems for Educational Organizations. Requirements with Guidance for Use", and to offer recommendations regarding the introduction thereof.

\section{PRESENTATION OF THE MAIN MATERIAL OF THE RESEARCH}

Records and methods. Academic publications, as well as systemic, logical, analytical and retrospect method.

Results and discussion. The education system today is the main social institution that defines the social and the state development. Of the three functions within the competence of the state - education, healthcare and protection - the education represents the major component that helps shape up the future, which means development, whereas all other functions focus primarily on preserving sustainability. The educational system is bound by yet another factor: the outcome of its functioning "the output product" and the ability to assess the quality thereof are rather far apart from the approval of management decisions, and this interval can be as long as it takes the degree program to go its full cycle, which is at least three years for high school and four to six years for higher education institutions. Another problem is to identify the performance indicators (not as much and not only quantitative but, above all, qualitative) of the educational system (in its entirety or individual elements thereof - educational institutions, research and auxiliary organizations and the management bodies themselves) that require the assessment. The fact that purely quantitative characteristics of their activities do not represent adequate indicators for the assessment of the performance of the system and its elements (which is specifically illustrated by the endless disputes about the concept of «quality of education», «quality of educational institution», "quality of management» and methods of the assessment thereof) requires no additional substantiation $[1,2]$.

Given the fact that any educational institutions primarily aims to provide the educational services, it would be safe to maintain that quality management in the higher education institutions shall be based primarily on the quality of educational services. Quality education or the output of a professional highly demanded by the employers primarily depend on the quality performance of the instructors.

The focus shift from the external control of the educational process quality and its results (the procedure that is based on the national attestation and accreditation systems) to the internal selfassessment of the higher education institutions (based on the appropriate quality management model) has become the major trend in the higher education quality assurance today. 
Implementation of the planned changes in the education system of Ukraine, particularly popularization of the education quality assurance systems that are consistent with the advanced international standards implies innovative approaches toward the selection of the teaching personnel by the educational institutions, organization of their professional performance and assessment of the latter. In the context of the existing problems, Priority tasks appear to be as follows: encourage the educators to keep improving their professional skills; popularize the pedagogic culture; promote the involvement of young personnel; create conditions for academic research by the educators.

It should be noted that the education system comprises of active elements that are fairly autonomous and sufficiently adaptable to the changing external environment and the management activities. And, considering the abovementioned interval between the approval of the decision and the "measurement" and assessment of the impact of such decision on the functioning of the system, the management bodies are apparently facing certain difficulties.

The education organization management system (EOMS) needs to factor in the described features of the controlled objects while simultaneously forming the management actions that would be consistent with the foreseeable "future", meaning it should proceed on the basis of a certain development model. In other words, there must a clear understanding that most of the management decisions made today will cause profound changes in the system only over a fairly long-term period, and, considering the adaptability of the elements, the actual results may profoundly differ from the expectations, including due to the changes in external environment.

All requirements in ISO 21001:2018 are generic and intended to be applicable to any organization that uses a curriculum to support the development of competence through teaching, learning or research, regardless of the type, size or method of delivery. It means that every educational institution may apply international standard ISO 21001:2018 [3].

The first essential aspect of ISO 21001:2018 is to promote the adoption of the process approach when developing, implementing and improving the effectiveness of an EOMS, to enhance learner and other beneficiary satisfaction by meeting learner and other beneficiary requirements. Understanding and managing interrelated processes as a system contributes to the organization's effectiveness and efficiency in achieving its intended results. This approach enables the organization to control the interrelationships and interdependencies among the processes of the system, so that the overall performance of the organization can be enhanced. The process approach involves the systematic definition and management of processes, and their interactions, so as to achieve the intended results in accordance with the policy, objectives and strategic plan of the organization. Management of the processes and the system as a whole can be achieved using the PDCA cycle with an overall focus on risk-based thinking aimed at taking advantage of opportunities and preventing undesirable results. The application of the process approach in an EOMS enables: understanding and consistency in meeting requirements; the consideration of processes in terms of added value; the achievement of effective process performance; improvement of processes based on evaluation of data and information. The EOMS entails the following management principles: focus on the client, visionary leadership, engagement of people, process approach, improvement, evidence-based decisions, relationship management, social responsibility, accessibility and equity, ethical conduct in education, data security and protection.

Risk-based thinking is essential for achieving an effective EOMS and represents another important aspect for the development and introduction of the requirements set forth in ISO 21001:2018 in the activity of an educational organization. To conform to the requirements of this standard, the organization needs to plan and implement actions to address risks and opportunities. Addressing both risks and opportunities establishes a basis for increasing the effectiveness of the quality management system, achieving improved results and preventing negative effects.

Opportunities can arise as a result of a situation favorable to achieving an intended result, e.g. a set of circumstances that allow the organization to attract learners and other beneficiaries, develop new products and services, reduce waste or improve productivity. Actions to address opportunities can also include consideration of associated risks. Risk is the effect of uncertainty and any such uncertainty can have positive or negative effects. A positive deviation arising from a risk can provide an opportunity, but not all positive effects of risk result in opportunities.

Basic concepts of ISO 21001:2018 include: process approach, risk-based thinking, activities based on the PDCA methodology and harmonized with ISO 9001:2015. According to the comparison of principles that serve as the basis for both standards (Fig.), a number of principles comprising ISO 21001:2018 are incidental solely to educational institutions. Standard ISO 21001 never once mentions the word "client" and specifically stipulates that the educational institution shall be committed to satisfaction of the needs of not just every acquirer but all other beneficiaries of educational services as well in the context of higher education, these are the labor market and the government. Pursuant to ISO 21001, acquirers of educational services shall take active part in self-education so as to reach its maximum potential. The standard requires the educational 


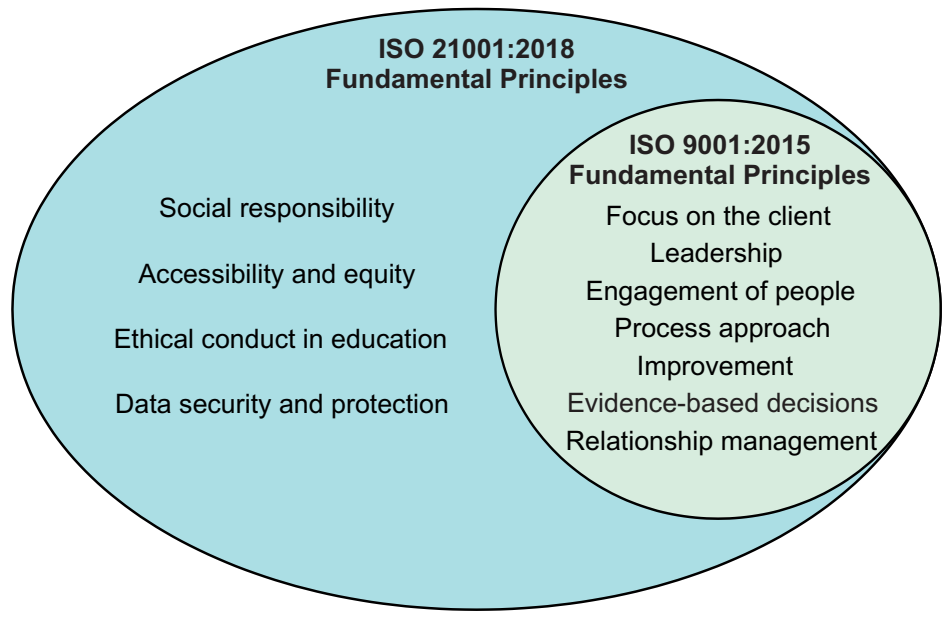

Fig. ISO 21001:2018 and ISO 9001:2015 Fundamental Principles

institutions to focus on the principles of social responsibility, accessibility and equity (maximum number of users shall have access to the educational services, and any such access shall be provided in an equitable manner); ethical conduct in education (honesty and professionalism to the benefit of the society); data security and protection (acknowledgment of the fact that the individuals have the right to control the use of their personal data and the educational institution shall keep and protect these data).

After analysing standard ISO 21001:2018, it should be mentioned that it is more competitive and personalized and focused on educational purposes.

As mentioned above, the standard ISO 21001:2018 is consistent with the standard ISO 9001:2015. But the implementation of ISO 21001:2018 requirements in the current QMS, namely: development of the concept of quality assurance of education; current monitoring and periodic review of the educational and methodological base, student-oriented learning, teaching and assessment; constant research of the educational services market, constant professional growth, recognition and confirmation of conformity; creation of educational content and student support; development of information management system; publicity of information and access to public information, - will allow higher education institutions to improve the quality of educational services, increase the competitiveness of higher education institutions, and in the strategic aspect - to stimulate the development of an innovative society.

In the past five years, quality management systems in accordance with ISO 9001 have implemented and successfully operate in medical and pharmaceutical higher education institutions. For example, the quality management system certified in accordance with ISO 9001 has implemented in the National University of Pharmacy in 2015. National University of Pharmacy sees its mission in the development of the national health sector through the comprehensive training of competent professionals at the level of standards of the European Higher Education Area.

Thus, the main advantages of management systems in the educational organization for conformity with the requirements of ISO 21001:2018 are: - formation of a holistic view of the educational service, better coordination of goals with the policy of the educational organization, increasing trust;

- increase of social responsibility, i.e. direct impact on the economy and society;

- adherence to the norms of academic integrity and professionalism in order to benefit society;

- continued support for improvement and innovation;

- use of continuous monitoring of educational processes and assessment tools designed to demonstrate and increase effectiveness and efficiency;

- more personalized learning and effective response to the requests of all students, including students with special educational needs, distance learning students, as well as providing opportunities for life long learning.

\section{CONCLUSIONS AND PROSPECTS OF FURTHER STUDIES}

1. International standard ISO $21001: 2018$ is a management tool for organizations providing educational products and services capable of meeting the learners' requirements. All providers of educational services will benefit from this standard: from kindergartens and secondary schools to the higher education institutions, as well as professional training centers and the suppliers of online training services.

2. It has been established that all requirements of ISO 21001:2018 are generic and intended to be applicable to any organization that uses a curriculum to support the development of competence through teaching, learning or research, regardless of the type, size or method of delivery. 
3. It has been proven that ISO $21001: 2018$ is based on process approach, risk-based thinking and activity that is based on the Plan-DoCheck-Act principle (PDCA).

4. It has been pointed out that introduction of the EOMS will help demonstrate the ability to support the acquisition and development of com- petence through teaching, learning or research, as well as to enhance satisfaction of learners, staff and other beneficiaries through the effective application of the EOMS, including continuous improvement of one's activity.

Conflict of interests: authors have no conflict of interests to declare.

\section{REFERENCES}

1. Воробйова О. П. Теоретико-методологічні засади формування стандартів забезпечення якості у галузі вищої освіти. Молодий вчений. 2018. № 1 (53). С. 273-277. URL: http://molodyvcheny.in.ua/files/ journal/2018/1/65.pdf

2. Про вищу освіту : Закон України від 14 лип. 2014 р. № 1556-VII. URL: https://zakon.rada.gov.ua/laws/ show/1556-18\#Text

3. ISO 21001:2018. Educational organizations - Management systems for educational organizations - Requirements with guidance for use. URL: https://www.iso.org/ru/standard/66266.html/

4. ДСТУ ISO 9001:2015 (ISO 9001:2015, IDT). Системи управління якістю. Вимоги. Офіц. вид. На заміну ДСТУ ISO 9001:2009 ; чинний від 01.07.2016. Київ : ДП «УкрНДНЦ», 2016. 24 с. (Національний стандарт України). URL: https://khoda.gov.ua/image/catalog/files/\%209001.pdf

5. ДСТУ ISO 9000:2015 (ISO 9000:2015, IDT). Системи управління якістю. Основні положення та словник термінів. Офіц. вид. На заміну ДСТУ ISO 9000:2007 ; чинний від 01.07.2016. Київ : ДП «УкрНДНЦ», 2016. 28 с. (Національний стандарт України). URL: https://khoda.gov.ua/image/catalog/files/\%209000.pdf

6. Досвід розробки та впровадження системи управління якістю підготовки фахівців з вищою освітою в Одеській національній академії зв'язку ім. О. С. Попова / П. П. Воробієнко та ін. Вища школа. 2013. № 6. С. 7-20.

7. Савченко С. О. Основні принципи процесного та проектного підходів в управлінні ВНЗ з орієнтацією на споживача. Глобальні та національні проблеми економіки. 2015. Вип. 6. С. 460-466. URL: http://global-national.in.ua/archive/6-2015/96.pdf

8. Станкевич I. В. Ідентифікація та моделювання бізнес-процесів системи управління якістю освітньої організації: теорія та практика. Проблеми економіки. 2017. № 1. C. 258-268. URL: https://www.problecon.com/export_pdf/problems-of-economy-2017-1_0-pages-258_268.pdf

9. Станкевич И. В. Основные подходы к выделению бизнес-процессов в образовательных организациях. Economic science. Science and education. 2014. Vol. 5 : Conduct of modern science: Materials of the X International scientific and practical conference, 30.11-07.12.2014, Sheffield, UK. P. 46-50.

\section{REFERENCES}

1. Vorobiova, O. P. (2018). Molodyi vchenyi, 1 (53), 273-277. Available at: http://molodyvcheny.in.ua/files/ journal/2018/1/65.pdf

2. Zakon Ukrainy vid 14 lyp. 2014 r. № 1556-VII «Pro vyshchu osvitu». zakon.rada.gov.ua. Available at: https://zakon.rada.gov.ua/laws/show/1556-18\#Text

3. Educational organizations - Management systems for educational organizations - Requirements with guidance for use. (2018). ISO 21001:2018. Available at: https://www.iso.org/ru/standard/66266.html/

4. Quality Management Systems. Requirements (ISO 9001:2015, IDT). (2016). DSTU ISO 9001:2015. Kyiv: $\mathrm{DP}$ «UkrNDNC», 24.

5. Quality Management Systems. Guidelines and Glossary (ISO 9000:2015, IDT). (2016). DSTU ISO 9000:2015. Kyiv: DP «UkrNDNC», 28.

6. Vorobiienko, P. P., Stankevich, I. V., Hlukhova, O. I., Sulima, L. O. (2013). Vyshcha shkola, 6, 7-20.

7. Savchenko, S. O. (2015). Hlobalni ta natsionalni problemy ekonomiky, 6, 460-466. Available at: http://globalnational.in.ua/archive/6-2015/96.pdf

8. Stankevych, I. V. (2017). Problemy ekonomiky, 1. 258-268. Available at: https://www.problecon.com/ export_pdf/problems-of-economy-2017-1_0-pages-258_268.pdf

9. Stankevych, I. V. (2014). Economic science. Science and education, 5: Conduct of modern science: materials of the X International scientific and practical conference (30.11-07.12.2014). (pp. 46-50). Sheffield.

Адреса для листування:

61140 , м. Харків, вул. О. Невського, 18.

Тел. (057) 771-81-47. E-mail: yezjf@nuph.edu.ua.

Національний фармацевтичний університет

Коваленко С. М. (ORCID - https://orcid.org/0000-0001-9473-685X)

Ромелашвілі O. C. (ORCID - https://orcid.org/0000-0002-7372-6406)

Зборовська Т. В. (ORCID - https://orcid.org/0000-0002-1670-3507)

Благун О. Д. (ORCID - https://orcid.org/0000-0001-9287-0430) 